\title{
PENERAPAN METODE DISKUSI KELOMPOK DALAM PEMBELAJARAN KONTEKSTUAL GUNA MENINGKATKAN HASIL BELAJAR IPS EKONOMI SISWA KELAS VII SMPN 2 DOLOPO MADIUN
}

\author{
Novita Erliana Sari \\ Dosen Prodi Pendidikan Ekonomi IKIP PGRI Madiun \\ Mahasiswa S2 Pendidikan Ekonomi
}

\begin{abstract}
:
This study aims to determine the presence or absence of the application of learning and improving student learning outcomes VIIB class second semester SMP Negeri 2 Dolopo with the implementation of Contextual Teaching and Learning with Discussion Group Methods on Economic social studies.
\end{abstract}

Subjects were VIIB semester grade SMP Negeri 2 Dolopo which are 32 students consisting of 19 male and 13 female. The procedure consisted of four series of activities done in repeated cycles with two cycles: (1) planning, (2) actions, (3) observation and (4) reflection. Data was collected through observation and tests.

The research proves that teachers' ability to apply learning with group discussions to enhance social studies learning outcomes Economic VIIB semester grade SMP Negeri 2 Dolopo Madiun.

In the discussion of learning techniques can be known active students during the learning process has increased. This can be shown by (a) Students were attentive and interested in learning to follow an increase in the first cycle 15 students or $46.87 \%$ in the second cycle to be 20 students or $62.50 \%$, (b) student activity in an increase in the expression in the first cycle a number of 13 students or $40.62 \%$ in the second cycle to 19 children, or $59.37 \%$, (c) student activity in response to what others have increased by $18.75 \%$ ie in the first cycle were 13 students or 40, 62\% while in the second cycle as many as 19 children, or 59.37\%, (d) involvement of the student in asking an increase, in the first cycle as many as 15 children, or $46.87 \%$, on the second cycle increased to 18 children, or $56.25 \%$ (e) active students in answering questions has increased in the first cycle were 13 students or $40.62 \%$, to 19 students or $59.37 \%$, $(f)$ student activity in an increase in cooperation, pasa first cycle were 19 students or $59,37 \%$ in the second cycle to be 24 students or $75 \%$.

Judging from the results of learning cycle I and cycle II obtained the following results: (a) the number of students who pass the study in the first cycle were 19 students or 59.37\%, while in the second cycle as many as 30 students or $93.75 \%$ indicating an increase amounted to $33.82 \%$, (b) from 32 students who take the test activities on the first cycle the total value obtained was 2210, while the second cycle increased to 2655, (c) the value of the average or mean in the first cycle was 70.94, while on the second cycle there is an increase as much as $12.03 \%$ to 82.97 , (d) the mean or median in the first cycle is $75.357 \%$, while in the second cycle increased to $85.333 \%$ showed an increase of $9.976 \%$, (e) mode 
or value that has the highest frequency in the first cycle was 75, while the mode in the second cycle was 85 showed an increase of 10 points, (f) the lowest value or the minimum in the first cycle was 45, while the lowest score was 55 in the second cycle showed an increase of 10 point, $(\mathrm{g})$ the maximum value in the first cycle was 85 , while in the second cycle was 95 showed an increase of 10 points.

Keywords: Method, Discussion Group, Contectual Teaching and Learning (CTL),

\section{Pendahuluan}

Tujuan pendidikan nasional menurut Undang-undang Sistem Pendidikan Nasional Tahun 2003, Bab II Pasal 3 Ayat 2 yaitu: "Pendidikan nasional berfungsi mengembangkan dan membentuk watak serta peradaban bangsa yang bermartabat dalam rangka mencerdaskan kehidupan bangsa, bertujuan untuk berkembangnya potensi peserta didik agar menjadi manusia yang beriman dan bertaqwa kepada Tuhan Yang Maha Esa, berakhlak mulia, sehat, berilmu, cakap, kreatif, mandiri dan menjadi warga negara yang demokratis serta bertanggungjawab (UU Sisdiknas, 2003:8)"

Upaya untuk meningkatkan sumber daya manusia salah satunya adalah dengan meningkatkan mutu pendidikan. Dalam rangka meningkatkan mutu pendidikan pemerintah berupaya meningkatkan kompetensi dalam kegiatan pembelajaran. Proses pembelajaran merupakan inti dari kegiatan pendidikan di sekolah yang dikembangkan oleh guru. Dengan pembelajaran yang tepat guru dapat menciptakan interaksi edukatif yang baik.

Dalam proses pembelajaran di sekolah ada dua subjek yang terlibat langsung dalam interaksi pada pembelajaran yaitu guru dan siswa. Kedua subjek tersebut memberikan kontribusi yang besar pada keberhasilan peserta didik yang nantinya menjamin keberhasilan tujuan pendidika secara optimal.

Dalam kegiatan pembelajaran banyak metode yang dapat digunakan oleh seorang guru. Namun demikian pada kenyataannya seringkali guru kurang memiliki kesadaran dalam menggunakan berbagai macam metode pembelajaran yang beraneka ragam tersebut karena diperlukan persiapan yang lebih matang dari metode pembelajaran yang biasa diterapkan. Sama seperti halnya pada proses 
pembelajaran pada siswa kelas VII SMPN 2 Dolopo Madiun mata pelajaran IPS Ekonomi yang seringkali menggunakan metode ceramah.

Ditinjau dari sisi positifnya teknik ceramah memiliki kekuatan untuk mengorganisir kelas serta mengendalikan interaksi yang berlebihan dan sangat tepat untuk menyajikan informasi sehingga seringkali menjadi pilihan guru untuk menyampaikan materi. Dalam teknik ceramah guru memiliki peran yang lebih aktif daripada siswa. Akibatnya siswa cenderung pasif dan kurang berkembang karena ia berperan sebagai penerima pesan yang disampaikan oleh informan tunggal yakni guru. Pembelajaran bersifat teacher centre sehingga penggunaan teknik ceramah dalam jangka waktu lama dikhawatirkan akan membuat siswa bosan dan setelah diamati dapat diketahui ternyata fokus terhadap pelajaran menjadi berkurang. Hal ini ditunjukkan dengan adanya beberapa siswa yang ramai sendiri ketika guru sedang menerangkan, beberapa siswa mengantuk terutama yang berada di belakang, ada pula siswa yang melamun dan menggambar saat kegiatan pembelajaran sedang berlangsung. Untuk itu guru diharapkan mampu menyajikan materi pelajaran dalam berbagai kreasi dan variasi sehingga kegiatan belajar menjadi lebih menarik, mampu menggugah semangat dan minat siswa untuk belajar dan pada akhirnya dapat dicapai hasil belajar yang memuaskan.

Pembelajaran kontekstual merupakan konsep belajar yang membantu guru mengaitkan antara materi yang diajarkan dengan situasi dunia nyata siswa dan mendorong antara pengetahuan yang dimilikinya dengan penerapan dalam kehidupan nyata sebagai anggota keluarga dan masyarakat. (Riyanto, 2009 : 161).

Pembelajaran kontekstual dapat diterapkan dengan berbagai macam metode. Salah satu metode yang dapat digunakan dalam pembelajaran kontekstual adalah metode diskusi kelompok.

Metode pembelajaran sangat banyak dan bervariasi, akan tetapi tidak semuanya dapat menghasilkan kebermaknaan. Salah satu metode pembelajaran yang diharapkan dapat mendukung pelaksanaan pembelajaran bermakna seperti halnya pembelajaran kontekstual adalah dengan penggunaan metode diskusi kelompok. 
Diskusi kelompok merupakan pembahasan suatu topik dengan cara tukar pikiran antara dua orang atau lebih, dalam kelompok-kelompok kecil, yang direncanakan untuk mencapai tujuan tertentu. Dalam diskusi kelompok ini kelas dibagi menjadi beberapa kelompok terdiri dari 3-5 orang. Tempat diskusi diatur agar siswa dapat berhadapan muka dan bertukar pikiran dengan mudah.

Hasil belajar yang diharapkan dari teknik ini adalah agar segenap individu membandingkan persepsinya yang mungkin berbeda-beda tentang bahan pelajaran, membandingkan interprestasi dan informasi yang diperoleh masingmasing individu yang dapat saling memperbaiki pengertian, persepsi, informasi, interprestasi sehingga diharapkan dapat menghindari kekeliruan.

Salah satu kebaikan metode diskusi menurut Martinis (Yamin, $2005: 70$ ), digunakan untuk membiasakan siswa menghadapi masalah secara bersama-sama, membiasakan diri untuk berargumentasi dan berfikir rasional. Untuk itu diskusi kelompok dinilai tepat untuk menerapkan pembelajaran kontekstual dengan karena dengan metode ini akan terjadi interaksi yang edukatif antara siswa dengan siswa maupun siswa guru. Selain itu pembelajaran tersebut juga akan lebih menarik karena memacu aktifitas siswa untuk lebih aktif dan kreatif.

Dalam metode pembelajaran diskusi kelompok guru bertindak sebagai pendamping belajar bukan informan tunggal bagi siswa, pembelajaran yang berlangsung bersifat student centre. Siswa didorong untuk lebih aktif dalam menggali dan membangun pengetahuan yang ada dalam dirinya. Dengan interaksi tersebut diharapkan antara siswa terjadi tukar pikiran dan argumen berdasarkan sejumlah informasi, peristiwa, pengalaman atau situasi kehidupan nyata yang didapat dan dialami siswa kemudian dihubungkan dengan materi pelajaran yang sedang dibahas. Nantinya siswa dapat mengambil manfaat dari apa yang telah dipelajari dan menerapkannya dalam kehidupan sehari-hari. Dengan demikian pembelajaran akan lebih berarti dan bermakna bagi siswa karena pembelajaran yang terjadi bukan sekedar mendengar, menerima, melihat dan menghafal. Oleh karena itu tujuan penelitian ini adalah untuk mengetahui sejauhmana peningkatan hasil belajar siswa kelas VIIB Semester Genap SMP Negeri 2 Dolopo Kabupaten Madiun pada mata pelajaran IPS Ekonomi. 


\section{Metode penelitian}

Penelitian ini dilaksanakan di SMP Negeri 2 Dolopo yang beralamat di Jl. Abimanyu No. 79 Dolopo Kabupaten Madiun. Penelitian ini dilakukan pada siswa kelas VIIB Semester Genap SMP Negeri 2 Dolopo Kabupaten Madiun. Subyek penelitian ini berjumlah 32 siswa yang terdiri dari 19 siswa laki-laki dan 13 siswa perempuan. Arikunto (2006 : 16) juga menyatakan bahwa "Ada beberapa ahli yang mengemukakan model penelitian tindakan dengan bagan yang berbeda naumun secara garis besar terdapat empat tahapan yang lazim dilalui yaitu (1) perencanaan, (2) pelaksanaan, (3) pengamatan dan (4) refleksi”.

Adapun model dan penjelasan untuk masing-masing tahapan adalah sebagai berikut:
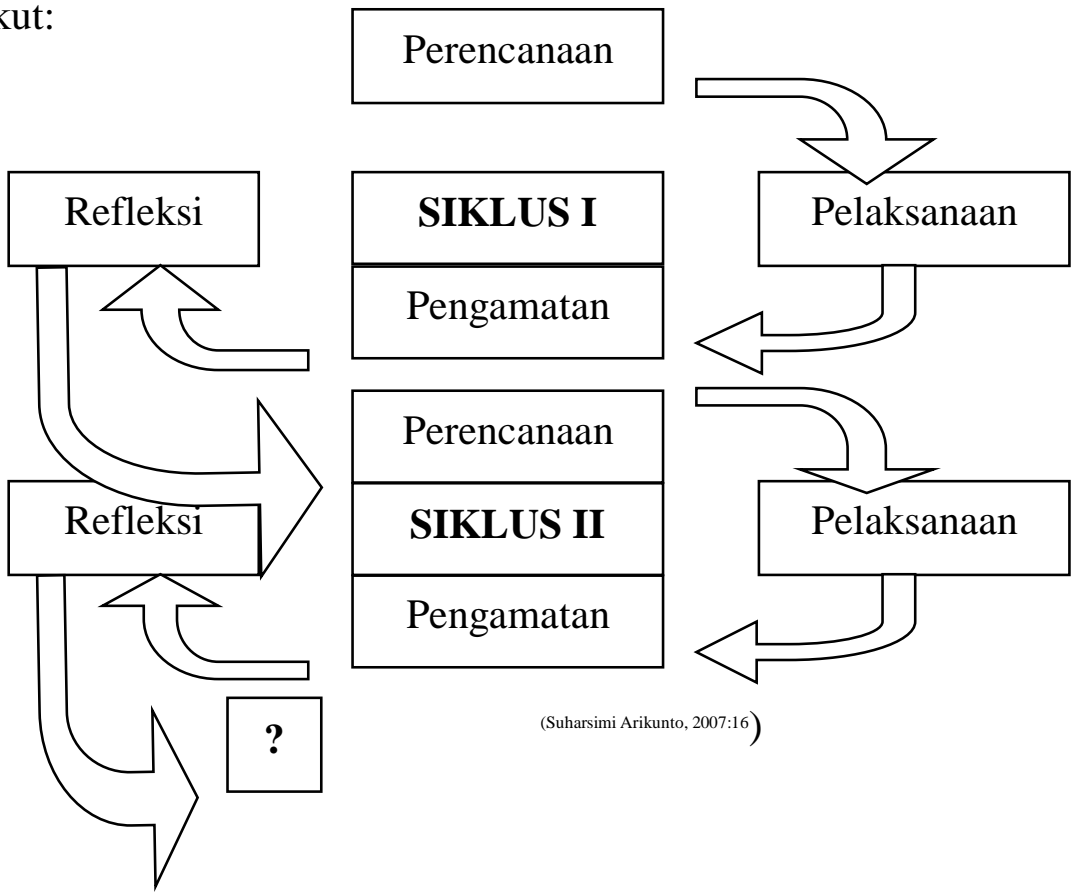

(Suharsimi Arikunto, 2007:16)

Adapun pelaksanaan berbagai tahap-tahap tersebut adalah sebagai berikut:

a. Tahap Perencanaan

Dalam tahap ini menjelaskan tentang apa, mengapa, kapan dimana, oleh siapa, dan bagaimana tindakan tersebut dilakukan (Arikunto, 2006 : 17). Langkah-langkah yang ditempuh adalah sebagai berikut.

1) Mengevaluasi jurnal, silabus dan hasil belajar siswa sebelum dilaksanakan pembelajaran dengan diskusi kelompok. 
2) Menyusun Rencana Pelaksanaan Pembelajaran dan silabus. Menentukan kompetensi dasar, dan indikator dengan alokasi waktu 2x45 menit. Dalam pembelajaran ini kompetensi dasar yang diambil adalah KD 6.2 yaitu mendeskripsikan kegiatan pokok ekonomi, yang meliputi kegiatan konsumsi, produksi, dan distribusi barang dan jasa.

3) Menyiapkan bahan dan materi pembelajaran yang digunakan dalam pembelajaran dengan teknik diskusi kelompok.

4) Membagi kelas menjadi beberapa kelompok.

5) Menyusun alat evaluasi untuk mengukur hasil belajar siswa setelah melaksanakan pembelajaran dengan diskusi kelompok. Instrumen yang digunakan dalam evaluasi untuk mengukur hasil belajar adalah soal tes objektif sebanyak 20 soal dan memberinya skor sebagai berikut:

a) skor 5 untuk jawaban benar pada setiap soal

b) skor 0 untuk jawaban salah

c) total skor keseluruhan 100 .

b. Tahap Pelaksanaan Tindakan

Langkah-langkah yang dilakukan peneliti adalah sebagai berikut.

1) Kegiatan Awal

a) Guru membuka pelajaran dengan salam.

b) Guru memeriksa presensi siswa

c) Guru menginformasikan kompetensi dasar dan indikator yang hendak dicapai.

d) Guru menyampaikan tujuan pembelajaran, model, metode dan teknik pembelajaran yang akan digunakan yaitu pembelajaran dengan diskusi kelompok.

e) Memberi pengantar untuk materi yang akan diajarkan.

2) Kegiatan Inti

a) Membagi siswa dalam beberapa kelompok

b) Membagi materi untuk didiskusikan siswa

c) Memotivasi, memfasilitasi kerja siswa, membantu siswa yang mengalami kesulitan dan mengamati kerjasama tiap kelompok 
d) Meminta juru bicara kelompok untuk menyampaikan hasil diskusinya

e) Mengontrol jalannya diskusi antar kelompok

f) Memberi penjelasan singkat dan penegasan kebenaran terhadap hasil diskusi masing-masing kelompok

3) Penutup

a) Memberi kesempatan siswa untuk bertanya.

b) Guru menyimpulkan semua materi yang telah dipelajari.

c) Guru mengadakan tes untuk mengetahui kemampuan dan minat siswa setelah melaksanakan pembelajaran dengan diskusi kelompok.

c. Tahap Pengamatan atau Observasi

Dalam penelitian ini yang diobservasi adalah pelaksanaan pembelajaran yang meliputi aktifitas guru dan siswa. Tujuan dilaksanakannya observasi ini adalah untuk mengetahui apakah guru telaha mengajar sesuai dengan metode diskusi kelompok.

Pada tahap ini guru mencatat hasil observasi dengan memakai format yang sudah ditetapkan untuk mengetahui kekurangan dan kelebihan poembelajaran pada siklus I.

d. Tahap Refleksi

Pada tahap ini peneliti dan guru mengulas tentang kekurangan dan kelemahan pelaksanaan tindakan yang telah dilaksanakan. Hasil refleksi ini digunakan untuk melakukan perbaikan dalam pembelajaran berikutnya.

Dari kekurangan pada siklus I maka peneliti melaksanakan proses pembelajaran dengan metode yang sama pada siklus II.

\section{Hasil Penelitian}

Berdasarkan pengamatan pada siklus I diperoleh data sebagai berikut.

\section{Pengamatan Guru}

a) Pada pertemuan pertama penyampaian materi pembelajaran telah sesuai dengan RPP tetapi karena siswa yang terlalu ramai dan banyak siswa yang tidak memperhatikan maka waktunya menjadi kurang.

b) Komunikasi antara guru dengan siswa sudah cukup baik, namun siswa dengan kemampuan sedang, kurang mendapat perhatian. 
c) Pembagian kelompok yang terdiri dari 5-6 orang merupakan kelompok yang efisien, namun motivasi terhadap masing-masing kelompok dirasa kurang.

d) Pada pertemuan kedua guru memberikan soal-soal untuk dikerjakan oleh siswa yang terdiri dari 20 soal objektif.

\section{Pengamatan Siswa}

a) Sebagian besar siswa belum mampu mengidentifikasi dan membedakan kegiatan ekonomi yang berupa produksi, konsumsi dan distribusi. Karena masih banyak siswa yang mengalami kesalahan dalam menjawab pertanyaan.

b) Siswa kurang menyerap apa yang telah diberikan sehingga bila ada teman yang bertanya masih belum bisa menjawab.

c) Siswa masih kesulitan bekerjasama dan berdiskusi sehingga dalam sebuah kelompok yang bekerja hanya satu, dua siswa.

d) Dalam menanggapi pendapat orang lain dan menjawab pertanyaan masih ada beberapa kelompok yang kurang aktif.

e) Siswa sangat antusias ketika mendapat kesempatan presentasi di depan kelas. Hasil observasi pada siklus I adalah sebagai berikut: rata-rata siswa yang perhatian dan berminat mengikuti pembelajaran sebanyak 15 siswa atau $46.87 \%$, rata-rata siswa yang mengemukakan pendapat sebanyak 13 siswa atau $40.62 \%$, rata-rata siswa yang menanggapi pendapat sebanyak 13 siswa atau $40.62 \%$, rata-rata siswa yang bertanya sebanyak 15 siswa atau $46.87 \%$, rata-rata siswa yang aktif menjawab pertanyaan sebanyak 13 siswa atau $40.62 \%$, rata-rata siswa yang aktif bekerjasama sebanyak 19 siswa atau $59.37 \%$. Hasil evaluasi pada proses pembelajaran dengan diskusi kelompok pada siklus I dapat diperoleh data atas dasar distribusi frekuensi bahwa siswa yang belum tuntas belajar pada siklus I adalah 13 siswa atau sebanyak $40.62 \%$, sedangkan sisanya sebanyak 19 siswa atau $59.93 \%$ sudah tuntas belajarnya. Diketahui mean 70.94, median 75.357 dan modus adalah nilai yang sering muncul sebanyak 14 kali, adalah nilai 75 .

Berdasarkan pengamatan guru dan siswa diperoleh hasil refleksi sebagai berikut. 
1. Sebelum pembelajaran diskusi berlangsung, kelas harus dikondisikan kondusif agar bahan diskusi yang diberikan oleh guru mudah diterima oleh siswa.

2. Bahan diskusi yang kurang jelas menyebabkan metode diskusi kelompok terhambat, karena pembelajaran masih didominasi oleh guru. Bahan diskusi perlu diperjelas.

3. Jumlah anggota kelompok yang terdiri dari 5-6 orang merupakan kelompok yang efisien, namun harus ada pembenahan dalam hal memberi motivasi terhadap masing-masing kelompok. Bukan hanya siswa yang menonjol saja yang dimotivasi tapi harus menyeluruh.

4. Guru hendaknya memberikan bimbingan yang lebih pada kelompok yang kurang aktif dalam menanggapi pendapat dan menjawab pertanyaan.

5. Penerapan metode diskusi kelompok belum dapat mencapai idikator kinerja yang diharapkan, karena ketuntasan belajar belum tercapai sesuai tolak ukur yang telah ditetapkan. Sehingga perlu dilanjutkan pada siklus II.

Berdasarkan pengamatan poada siklus II diperoleh data sebagai berikut.

1. Pengamatan guru

a) Guru mampu mengondisikan kelas sebelum pembelajaran dimulai sehingga kelas sudah lebih kondusif.

b) Penyampaian materi pembelajaran oleh guru sudah sesuai dengan RPP.

c) Pengelolaan pembelajaran sudah lebih baik karena guru dan siswa telah memahami teknik pelaksanaannya.

d) Guru sudah mampu memantau aktifitas siswa, siswa yang pasif dan tidak tertib dapat diatasi oleh guru.

e) Pemberian motivasi oleh guru sudah semakin baik, tidak hanya siswa yang menonjol saja yang dimotivasi, namun sudah menyeluruh.

\section{Pengamatan Siswa}

a) Suasana kelas tertib dan terkendali.

b) Keberanian dan antusias siswa semakin meningkat.

c) Kerjasama antar siswa dalam maupun diluar kelompok semakin meningkat. Hasil observasi pada siklus I adalah sebagai berikut: rata-rata siswa yang perhatian dan berminat mengikuti pembelajaran sebanyak 20 siswa atau 
$62.50 \%$, rata-rata siswa yang mengemukakan pendapat sebanyak 19 siswa atau $59.37 \%$, rata-rata siswa yang menanggapi pendapat sebanyak 19 siswa atau $59.37 \%$, rata-rata siswa yang bertanya sebanyak 18 siswa atau 56.25 $\%$, rata-rata siswa yang aktif menjawab pertanyaan sebanyak 19 siswa atau $59.37 \%$, siswa yang aktif bekerjasama sebanyak 24 siswa atau $75 \%$, siswa yang belum tuntas belajar pada siklus II apabila KKM 66 adalah 2 siswa atau sebanyak $6.25 \%$ sedangkan sisanya sebanyak 30 siswa atau 93,75 sudah tuntas belajarnya. Mean pada siklus II mencapai 82.97, median pada siklus II mencapai 85.333, sedangkan modus (nilai yang sering muncul) yaitu nilai yang memiliki frekuensi terbanyak yaitu 9, sehingga dapat diketahui nilai yang paling banyak diperoleh siswa adalah 80 .

Ketidakberhasilan penelitian pada siklus I ini disebabkan sebagai berikut.

1. Pada siklus I penyampaian materi diskusi kelompok masih kurag jelas, sehingga siswa sulit mengulas materi yang telah diberikan dan pada akhirnya siswa cenderung pasif ketika diskusi kelompok sedang berjalan.

2. Tingkat kerjasama yang masih sangat kurang diantara anggota kelompok, hanya satu, dua siswa saja yang aktif dalam kelompok.

3. Tingkat keberanian siswa dalam bertanya maupun mengutarakan pendapat masih sangat rendah.

4. Dalam proses pembelajaran guru kurang menguasai kelas sehingga siswa cenderung ramai, gaduh dan tidak tertib.

5. Motivasi yang diberikan oleh guru belum menyeluruh, hanya terbatas pada siswa yang menonjol sedangakan yang memiliki kemampuan menengah kebawah cenderung diabaikan.

Keberhasiln pada siklus II disebabkan oleh:

1. Metode diskusi kelompok yang diterapkan oleh guru menjadikan siswa berminat belajar, berani bertanya dan berpendapat sehingga kegiatan pembelajaran menjadi hidup.

2. Adanya kerjasama antar siswa dalam maupun diluar kelompok.

3. Tingkat keaktifan siswa, kebernian bertanya dan berpedapat siswa dalam pembelajaran yang meningkat. 
4. Guru sudah mampu menguasai kelas sehingga kelas menjadi kondusif, tertib dan nyaman untuk pelaksanaan pembelajaran diskusi kelompok.

5. Guru sudah mampu memberikan motivasi secara menyeluruh, tidak terbatas pada siswa yang menonjol saja, sehingga siswa juga termotivasi dalam kegiatan pembelajaran dengan metode diskusi kelompok.

6. Pembelajaran pada siklus II lebih baik daripada siklus I, karena antara guru dan siswa telah memahami metode pembelajaran diskusi kelompok.

\section{Penutup}

\section{Simpulan}

Pelaksanaan penelitian tindakan kelas dengan metode diskusi kelompok pada siklus I menunjukkan bahwa diskusi kelompok dapat meningkatkan hasil belajar siswa. Peningkatan hasil belajar siswa tersebut dapat dilihat dari nilai ratarata hasil belajar pada siklus I mencapai 70,94, akan tetapi penelitian belum berhasil dan perlu dilanjutkan ke siklus II karena tingkat ketuntasan belajar belum mencapai sesuai tolak ukur yang titetapkan. Sedangkan pada siklus II terjadi kenaikan hasil evaluasi menjadi 82,97.

\section{Saran}

Dengan memperhatikan hasil penelitian dan kesimpulan diatas, maka beberapa saran yang dapat diberikan adalah sebagai berikut.

1. Dalam proses pembelajaran hendaknya seorang guru menggunakan variasi metode sehingga memungkinkan siswa berani mengemukakan pendapat dan berpartisipasi aktif dalam pembelajaran.

2. Jika seorang guru menerapkan metode diskusi kelompok, hendaknya guru menyampaikan langkah-langkah pembelajaran secara jelas sehingga pembelajaran mampu berjalan dengan baik.

3. Dalam penerapan teknik pembelajaran dengan diskusi kelompok diharapkan guru memiliki kesiapan yang lebih matang, mampu membimbing dan memotivasi siswa agar setiap anggota kelompok berpartisipasi secara aktif dalam kegiatan pembelajaran. 
4. Indikator yang akan dicapai dalam pembelajaran hendaknya disampaikan kepada siswa sehingga siswa mengetahui tujuan pembelajaran dan mengetahui apa yang harus dilakukan dalam pembelajaran.

5. Dalam penerapan metode diskusi kelompok guru mampu membimbing siswa.

6. Siswa harus saling menghormati pendapat teman didalam maupun diluar kelompoknya.

\section{DAFTAR PUSTAKA}

Agus Suprijono. 2009, Cooperative Learning. Yogyakarta: Pustaka Pelajar.

Basrowi dan Suwandi. 2008, Prosedur Penelitian Tindakan Kelas. Bogor: Ghalia Indonesia.

Dalyono. 2001, Psikologi Pendidikan. Jakarta: Rineka Cipta.

Departemen Pendidikan Nasional Direktorat Jndral Pendidikan Dasar dan Menengah Direktorat Tenaga Kependidikan. 2004, Interaksi Belajar Mangajar dan Penelitian Tindakan Kelas.

Elaine B. Johnson. 2006, Contextual Teaching and Learning. Bandung: MLC.

Enco Mulyasa. 2004, Implementasi Kurikulum. Bandung: Remaja Rosdakarya.

Hamzah B. Uno. 2007, Model Pembelajaran. Jakarta: Bumi Aksara.

Nana Syaodih Sukmadinata. 2005, Landasan Psikologi Proses Pendidikan. Bandung: Remaja Rosdakarya.

Pupuh Faturrohman dan M. Sobri Sutikno. 2007, Strategi Belajar Mengajar. Bandung; Refika Aditama.

Retno Widyaningrum. 2009, Statistik. Ponorogo: Stain Press.

Rochiati Wiriaatmadja. 2007, Metode Penelitian Tindakan Kelas. Bandung: Remaja Rosdakarya.

Slameto. 2003, Belajar dan Faktor - Faktor Yang Mempengaruhinya. Jakarta: Rineka Cipta.

Suherli. 2009, Model Pembelajaran Kontekstual. Dalam Beranda Irfa Razak. http:Imodel-pembelajaran- $\quad$ kontekstual. Diakses tanggal 10 Maret 2010. 
Suharsimi Arikunto. 2006, Penelitian Tindakan Kelas. Jakarta: Bumi Aksara.

Syaiful Bahri Djamarah. 2002, Prestasi Belajar dan Kompetensi Guru. Jakarta: Rineka Cipta.

Undang-undang Republik Indonesia Nomor 20 Tahun 2003 tentang Sistem Pendidikan Nasional. Bandung: Citra Umbara.

Wina Sanjaya. 2009, Strategi Pembelajaran Berorientasi Standar Proses Pendidikan. Jakarta: Kencana Prenada Media Group.

Wina Sanjaya. 2005, Pembelajaran Dalam Implementasi Kurikulum Berbasis Kompetensi. Jakarta: Kencana Prenada Media Group.

Yatim Riyanto. 2009, Paradigma Baru Pembelajaran. Jakarta: Kencana Prenada Media Group. 